\title{
Determination of Pumpkin Leaves Equivalent; As a Measure of Pyhto Toxicity on Human Erythrocytes
}

\author{
Ibeh Nnanna Isaiah $^{1 *}$, Okungbowa Awo Micheal ${ }^{2}$
}

\begin{abstract}
${ }^{1}$ Faculty of Veterinary Medicine, Department of Anatomy, University of Benin, 1154, P.M.B, Ugbowo Lagos Rd, Benin City, Nigeria
${ }^{2}$ Faculty of Basic Medical Sciences, Department of Medical Laboratory Sciences, University of Benin, 1154, P.M.B, Ugbowo Lagos Rd, Benin City, Nigeria
\end{abstract}

DOI: $10.36347 /$ sajb.2020.v08i06.003

| Received: 06.06.2020 | Accepted: 13.06.2020 | Published: 16.06.2020

*Corresponding author: Ibeh Nnanna Isaiah

Abstract

Original Research Article

Pumpkin leaves (Telfairia occidentalis) are extensively used in homes in Nigeria and some West African Countries for soup making and sometimes extracted in water for drinking as medicament for stimulating erythropoiesis. The present study aims at evaluating the in-vitro effect of pumpkin leaves extract on human erythrocytes with an interest in obtaining base data on the phyto-toxicity as a measure to determine the toxicity of other trado-phyto extract on human erythrocyte. Human erythrocytes of the A,B,O blood groups and Rhesus positive and negative were obtained from blood donors in the University of Benin Teaching Hospital, Benin City. Pumpkin leaves weighing 250g was extract in $250 \mathrm{ml}$ cold distilled water to obtain a stock solution of $1 \mathrm{gm} / \mathrm{ml}$ pumpkin leaves extract. The stock solution was further diluted in sterile test tubes to obtain a concentration range of $10 \mu \mathrm{g} / \mathrm{m} /, 20 \mu \mathrm{g} / \mathrm{m} /, 40 \mu \mathrm{g} / \mathrm{m} /$ to $640 \mu \mathrm{g} / \mathrm{m} / \mathrm{using}$ cold sterile distilled water. The heamolysis occurring in the tubes was read spectrophometrically (Cornings) at 540nm wavelength along with the neat and saline control. A drop of erythrocyte suspension $(0.02 \mathrm{ml})$ from each tube was placed on a clean grease- free slide, covered with a coverslip and examined under the microscope (Olympus) using X10 and X40 objective lenses. Then photomicrographs to show cell structures were obtained using a motic camera with extension lense. The lowest concentration of pumpkin leaves extract to yield heamolysis was $125 \mu \mathrm{g} / \mathrm{m} /$ irrespective of blood group and Rhesus status. To determine the equivalent of other phyto-product using the equivalent is calculated using the least concentration which had the least hemolysis on Telfaira occidentalis divided by the least concentration of other phyto-extract. The equivalent greater than one (1>) shows that the toxicity is higher than Telfaira occidentalis, the equivalent $(<1)$ less than one shows a toxicity lower than pumpkin equivalent but the when it is equals to one $(1)$, it is equals to that of pumpkin. The data obtained from this study may have value in determining phytotoxicity with pumpkin leaves.

Keywords: Pumpkin leaves (Telfairia occidentalis), in-vitro, phyto-toxicity, Human erythrocytes.

Copyright @ 2020: This is an open-access article distributed under the terms of the Creative Commons Attribution license which permits unrestricted use, distribution, and reproduction in any medium for non-commercial use (NonCommercial, or CC-BY-NC) provided the original author and source are credited

\section{INTRODUCTION}

Telfairia occidentalis is a vital staple vegetable big in Nigeria. Recent studies have shown that Telfairia occidentalis leaf is wealthy in mineral components (such as iron, potassium, sodium, phosphorus, metal and magnesium), antioxidants, vitamins (such as vitamin B, riboflavin, ascorbate), nicotinamide and phytochemicals [1].

The amino acid profile of $T$. occidentalis seeds had conjointly been shown to be nutritious with the amino acid, aspartate, glycine, glutamine, histidine, lysine, methionine, tryptophan, cystine, leucine, arginine, serine, threonine, essential amino acid, valine, amino acid and essential amino acid [2, 3].
Following a line of investigation, facts have been established on the biological significance of Telfairia Occidentalis seeds. The seeds are extremely healthy, moreover it helps loosen the alimentary. They are eaten up, either roasted or stewed. They are conjointly used as soup thickeners [4]. The seed is extremely rich in oil, particularly unsaturated fatty acids. $61 \%$ of the oil [5-7] have documented that Fluted pumpkin seeds are a honest supply of 4 mineral components $(\mathrm{Ca}, \mathrm{K}, \mathrm{Na}, \mathrm{Zn})$ needed in human nutrition. The report showed that the seed contained 29 oil and half-hour supermolecule [1]. Fluted pumpkin seed contain 47 oil and 31 supermolecule. The supermolecule is aforesaid to be markedly deficient with the sulphur-containing aminoalkanoic acid. 
Previous studies has it that Fluted pumpkin seeds had $53 \%$ fat, $22 \%$ supermolecule, $3 \%$ fibre, $15 \%$ carbohydrates and $2 \%$ ash [9-11]. Oyolu determined that vegetables can still stay the first supply of proteins, minerals and vitamins in African countries, he noted that leaves and edible shoots of Fluted pumpkin along contain $85 \%$ liquid content, whereas the dry portion of what's sometimes consumed contains $11 \%$ Martinmas crude protein, $25 \%$ carbohydrate, $3 \%$ oil, $11 \%$ ash and the maximum amount of iron as 700 ppm [13-15].

\section{Medicinal Plant Toxicity}

In geographic region, ancient medication is widely utilized in rural and concrete areas conjointly. this can be basically due to the preventive value of pharmaceutical-based medication and also the low incomes of a serious a part of the population additionally, the efficacies of the many of those ancient and plant-based medicines, however the actual fact remains that some plants utilized in ancient medication have cytotoxic effects [8-10]. It's during this perspective that we tend to investigate the literature on the toxicity of plants utilized in ancient medication. It's crucial to achieve data on these plant-based medicines prescribed by practitioners, significantly in terms of toxicity, composition, specific effectuality of malady and to advise practitioners of this practice of medicine on the protection and security of patients $[8,9,15,16]$.

The World Health Organization calculate that maybe $80 \%$ of the inhabitants of the planet believe mainly on ancient medicines. It, therefore, approved the employment of flavored merchandise for national policies and drug regulative measures so as to strengthen analysis and analysis of the protection and effectuality of flavored merchandise. The report has steered up to 119 plant derived drug listed by World Health Organization study, seventy four (74) were discovered as a results of chemical studies to isolate the active compounds accountable for the employment of original plant in ancient medication [17].

\section{Acute Toxicity}

Acute cytotoxicity is outlined because the toxic effects created by single exposure of medication by any route for a brief amount of your time (UWCSDG, 1999). Acute toxicity studies in animals are required for any pharmaceutical meant for human use. The most objective of acute toxicity studies is to spot one dose inflicting major adverse effects or life threatening toxicity, which frequently involves associate degree estimation of the minimum dose inflicting morbidity. The studies are typically meted out in rodents and carries with it one dose. In pharmaceutical drug development, this can be the sole study kind wherever pathology or critical toxicity is associate degree end as documented in current regulative pointers [18]. To measure the toxicity of a compound in animals, varied routes could also be used, however 2 most typically used modes of administration for animals studies are via intraperitoneal injection or the oral route $[18,19]$.

Usually acute (single dose) toxicity study is meted out on laboratory animals by victimization high dose (sufficient to supply death or morbidity) of the substance in question and/or supported previous report on its toxicity or toxicity of structurally connected compounds [4, 5]. Acute toxicity studies are unremarkably wont to verify LD50 of drug or chemicals [20]. The acute study provides a suggestion for choosing doses for the sub-acute and chronic low dose study, which can be clinically additional relevant $[21,22]$.

\section{Sub-Acute Toxicity}

In sub-acute toxicity studies, repeated doses of drug are given in sub-lethal quantity for a period of 14 to 21 days. Sub-acute toxicity studies are used to determine effect of drug on biochemical and hematological parameters of blood as well as to determine histopathological changes $[21,22]$.

\section{Chronic Toxicity}

In chronic toxicity studies, drug is given in different doses for a period of 90 days to over a year to determine carcinogenic and mutagenic potential of drug [21-23]. The parameters of chronic toxicity studies are same as that of sub-acute study. Multiple dose studies are necessary to assure the safety of natural products [23, 24].

On the other hand clinical observations of acute assays are valuable tools to define the doses to be tested in multiple dose experiments, along with pharmacological studies in animals and in humans [25].

\section{METHODOLOGY \\ Phyto Material Extraction}

The Leaves of the plant were collected, dried in the shade and powdered using mortar and pestle. The powdered processed leaves were stored in airtight containers and labeled properly. Each of the dried grounded material weighed $500 \mathrm{~g}$. Extraction of the phyto product was carried out using 2Lof methanol and normal salineby cold maceration for7days in large amber bottles with intermittent shaking. Filtration using the Whatman filter paper (No 42) was used to separate the artifacts and macro substance.

\section{Sample Size}

The minimum sample size in this study is determined by [10].

$$
\mathrm{n}=\mathrm{Z}^{2} \mathrm{pq} / \mathrm{d}^{2}
$$

$\mathrm{n}=$ minimum sample size

$\mathrm{z}=\mathrm{is}$ thevalue ofthe normal curve corresponding to $95 \%$ confidence interval $=1.96 \mathrm{p}=$ prevalenceof LD50 of Pumpkin extract is at $=5 \%=0.05$ and $q=1-p$ i.e. $1-$ 
Ibeh Nnanna Isaiah \& Okungbowa Awo Micheal., Sch Acad J Biosci, June., 2020; 8(6): 153-160

$0.05=0.95$

$\mathrm{d}=$ level of significance or error margin $=5 \%$

$\mathrm{n}=1.96^{2} \mathrm{x} 0.05 \times 0.95 / 0.05^{2}=72 . .9$

Minimum sample number $=73$.

\section{Collection of Blood and Preparation for analysis}

Using a sterile five milliliter syringe, five milliliters of blood was collected by veni-puncture from the cubital fossa of healthy patients without gender discrimination. The blood was dispensed into sodium EDTA specimen bottles (green cap), it was mixed gently and thoroughly rolling the bottle. Centrifugation was carried out to separate plasma from the packed erythrocytes. The separated packed erythrocytes were washed 3 times with phosphate buffered normal saline and the supernatant decanted. The time of centrifugation was 5 mins at a speed of $626(\mathrm{xg})[6,7,25,26]$. The washed packed cells were used for the toxicity test by in vitro red cell hemolysis) $[6,7,25,26]$.

\section{Haemolysis Study}

The properties of Pumpkin extract that provide compatibility of the formulation to the cells are the lipids having biocompatibility to the blood cells. Toxicity on the blood cells gives a primary idea of the effect of the pumpkin extract on the red blood cells of the body apart from giving an apparent idea on the compatibility with blood cells. RBCs may cause electrolyte loss as well as inducing immunological reactions inside the cell leading to RBC death which usually follows loss of hemoglobin from RBCs.

Thus hemolysis potential of the liposomes is necessitated to be evaluated. Hemolytic toxicity of pumpkin equivalent was checked by incubating the formulations with Red Blood Cells separated from Human blood by centrifugation at low speed and analyzing the samples for hemoglobin release at $541 \mathrm{~nm}$. Hemolysis with different formulations were compared with that obtained with Triton $-\mathrm{X} 100$ as a positive control) $[27,28]$.

\section{Cell Viability Test}

Hemolysis potentials of the pumpkin leave extract equivalent were added to the RBC concentrate and gently mixed. The concentrate was then incubated at $37^{\circ} \mathrm{C}$ for $30 \mathrm{~min}$ in incubator.

After incubation it is again at $3000 \mathrm{rpm}$ for 5 min to separate the pellet. The supernatant was analyzed for absorbance at $540 \mathrm{~nm}$ in UV spectrophotometer against normal saline as blank.

Percentage of hemolysis was determined for different samples considering the absorbance value of sample treated with $0.5 \%$ Triton-X100 to represent 100 $\%$ hemolysis and normal saline treated samples to serve as negative control. \% relative hemolysis was determined by following expression.
\%100-(Abs Sample- Abs Negative)

(Abs Neg-Abs Posi)-100

\section{Determination of Pumpkin Leaf Equivalent} Pumpkin Leave Equivalent $(\mathrm{PLE})=\mathrm{U} / \mathrm{P} \times 100$

$\mathrm{U}=($ Hemolytic concentration of the unknown) $\mathrm{P}=($ Minimal hemolytic concentration of Pumpkin leaves)

PLE is in $\mu \mathrm{g} / \mathrm{ml}$ and from the toxicological point of view useful values range from

$>1=$ More toxic than Telfaira occidentalis

$\leq 1=$ Less Toxic or as phyotoxic as Telfaira occidentalis) [27].

\section{Statistical Analysis}

Statistical analysis including descriptive statistics will be carried out using the Statistical Package (Graph Pad Prism). All values will be expressed as Mean \pm S.E (Mean standard error of mean). The analysis of variance (ANOVA) will be used to determine significant difference in test and control groups $(\mathrm{p}<0.05)$ at confidence limit will be set at $95 \%$.

\section{RESULTS}

The Pumpkin equivalent was determined comparing the least and the highest dose concentration gradient $(125,250,500$ and $1000 \mu \mathrm{g})$. The concentration gradient is compared with an equivalent hemolytic assay of Human red blood cells in Phosphate buffered saline was determined and termed the pumpkin equivalent (Table 4.1 and 4.2).

The absorbance values of the aqueous extract of pumpkin leaves, bitter leave and scent leave at $125 \mu \mathrm{g}$ concentration and the various $\mathrm{ABO}(\mathrm{O}, \mathrm{A}, \mathrm{B}$ and $\mathrm{AB})$ blood grouping system were $(0.3953 \pm 0.005$, $0.3963 \pm 0.007,0.3722 \pm 0.010$ and $0.3953 \pm 0.005)$. The absorbance values of Aqueous extract of bitter leave at $125 \mu \mathrm{g} \quad$ were $(0.4818 \pm 0.003, \quad 0.4808 \pm 0.017$, $0.4983 \pm 0.011$ and $0.4818 \pm 0.050)$. Comparatively the highest absorbance values at $125 \mu \mathrm{g}$ concentrations were observed in the Scent leave extract with $(0.4860 \pm 0.019$, $0.5069 \pm 0.025,0.5012 \pm 0.016$ and $0.4860 \pm 0.019)$. There were observable significant difference $(\mathrm{p}<0.005)$ when comparing the effect of the various leave extract on the $\mathrm{ABO}$ blood groups $(\mathrm{O}, \mathrm{A}, \mathrm{B}$ and $\mathrm{AB})$ with the pumpkin extract showing the least toxicity in vitro on the Human red blood cells ( Table 4.3).

At $250 \mu \mathrm{g}$ concentration of the aqueous leaves extract on the $\mathrm{ABO}(\mathrm{O}, \mathrm{A}, \mathrm{B}$ and $\mathrm{AB})$ blood grouping system the absorbance values were $(0.3424 \pm 0.008$, $0.3504 \pm 0.010, \quad 0.3478 \pm 0.007$ and $0.3575 \pm 0.010$ ). Aqueous extract of bitter leave at $250 \mu \mathrm{g}$ were $(0.8072 \pm 0.01, \quad 0.800 \pm 0.012, \quad 0.7576 \pm 0.01 \quad$ and $0.8170 \pm 0.01)$. The highest absorbance values at $250 \mu \mathrm{g}$ 
concentration were observed in the Scent leave extract with $(0.7202 \pm 0.020,0.7281 \pm 0.020,0.6972 \pm 0.016$ and $0.7039 \pm 0.020)$. There were observable significant difference $(\mathrm{p}<0.005)$ when comparing the effect of the various leave extract on the $\mathrm{ABO}$ blood groups $(\mathrm{O}, \mathrm{A}, \mathrm{B}$ and $\mathrm{AB}$ ) with the pumpkin extract showing the least toxicity in vitro on the Human red blood cells (Table 4.3).

At $500 \mu \mathrm{g}$ concentration of the aqueous leaves extract on the $\mathrm{ABO}(\mathrm{O}, \mathrm{A}, \mathrm{B}$ and $\mathrm{AB})$ blood grouping system the absorbance values were $(1.078 \pm 0.02$, $1.102 \pm 0.03, \quad 1.081 \pm 0.02$ and $1.087 \pm 0.02)$.Aqueous extract of bitter leave at $500 \mu \mathrm{g}$ were $(1.203 \pm 0.03$, $1.222 \pm 0.03,1.315 \pm 0.04$ and $1.220 \pm 0.03)$. The highest absorbance values at $500 \mu \mathrm{g}$ concentration were observed in the Scent leave extract with $(1.160 \pm 0.02$, $1.162 \pm 0.02,1.116 \pm 0.02$ and $1.162 \pm 0.02)$. There were observable significant difference $(p<0.005)$ when comparing the effect of the various leave extract on the ABO blood groups $(\mathrm{O}, \mathrm{A}, \mathrm{B}$ and $\mathrm{AB})$ with the pumpkin extract showing the least toxicity in vitro on the Human red blood cells (Table 4.4).

At $1000 \mu \mathrm{g}$ concentration of the aqueous leaves extract on the $\mathrm{ABO}(\mathrm{O}, \mathrm{A}, \mathrm{B}$ and $\mathrm{AB})$ blood grouping system the absorbance values were (1.662 \pm 0.01 , $1.782 \pm 0.06, \quad 1.677 \pm 0.01$ and $1.783 \pm 0.03)$.Aqueous extract of bitter leave at $500 \mu \mathrm{g}$ were $(1.943 \pm 0.02$, $2.519 \pm 0.22,2.043 \pm 0.04$ and $2.763 \pm 0.19)$. The highest absorbance values at $500 \mu \mathrm{g}$ concentration were observed in the Scent leave extract with $(1.881 \pm 0.01$, $1.959 \pm 0.02,1.925 \pm 0.01$ and $1.933 \pm 0.02)$. There were observable significant difference $(p<0.005)$ when comparing the effect of the various leave extract on the $\mathrm{ABO}$ blood groups $(\mathrm{O}, \mathrm{A}, \mathrm{B}$ and $\mathrm{AB})$ with the pumpkin extract showing the least toxicity in vitro on the Human red blood cells (Table 4.5).

The percentage hemolysis of aqueous extract of scent leave equivalent at 125,250,500 and $1000 \mu \mathrm{g}$ on the $\mathrm{ABO}$ blood groups $(\mathrm{O}, \mathrm{A}, \mathrm{B}$ and $\mathrm{AB})$ were, $125 \mu \mathrm{g}$ (6.7,7.4,7.3 and 6.7), $500 \mu \mathrm{g}(15.3,13.6,14.5$ and 14.7), $500 \mu \mathrm{g}(38.4,38.4,38.6$ and $38.4 \%)$ and $1000 \mu \mathrm{g}$ $(58,60,59.7$ and 60.0) (Table 4.10, 4.11, 4.12 and 4.13).

The percentage hemolysis of aqueous extract of bitter leave equivalent at $125,250,500$ and $1000 \mu \mathrm{g}$ on the $\mathrm{ABO}$ blood groups $(\mathrm{O}, \mathrm{A}, \mathrm{B}$ and $\mathrm{AB})$ were, $125 \mu \mathrm{g}$ (6,6.5,7.2 and 6.2\%), $250 \mu \mathrm{g}(18.5,16.3 .16 .7$ and 18.9), $500 \mu \mathrm{g}(33.8,37.2,33.7$, and 33.1) and $1000 \mu \mathrm{g}$ $(60,81.5,64.0$ and $90.5 \%$ ) (Table 4.14, 4.15, 4.16 and 4.17).

The mean \pm SEM comparative percentage hemolysis of the various extract of (Pumpkin, Scent and Bitter leave) at 125,250,500 and $1000 \mu \mathrm{g}$ on Human red blood cells were $125 \mu \mathrm{g}(12.85 \pm 0.184,16.30 \pm 0.178$ and $16.05 \pm 0.1500), 250 \mu \mathrm{g}(11.55 \pm 0.104,23.5 \pm 0.240$ and $26.28 \pm 0.44), \quad 500 \mu \mathrm{g} \quad(35.8 \pm 0.09, \quad 38.45 \pm 0.05$ and $41.0 \pm 0.84)$ and $1000 \mu \mathrm{g}(57.0 \pm 1.15,63.63 \pm 0.59$ and $76.68 \pm 6.43)$. As the concentration gradient increased there is a significant difference in their various levels of hemolysis. At $250 \mu \mathrm{g}$ of pumpkin extract the hemolysis is at $11.55 \%$ which is significantly lower than the other concentration gradient $(\mathrm{P}<0.005)$ and determined as the equivalent dose (Table 4.18 and 4.19).

Table 1.0: Effect of Pumpkin leaves, Scent Leaves and Bitter Leaves extract on the percentage Heamolysis Human erythrocytes, comparing the control groups and the treated groups across the various concentration gradient

\begin{tabular}{|c|c|c|c|c|c|c|c|}
\hline & $\begin{array}{l}\text { TRITON } \\
\mathbf{X}(\mathbf{n}=5)\end{array}$ & $\begin{array}{l}\text { PBS } \\
(n=5)\end{array}$ & $\begin{array}{l}125 \mu \mathrm{g} \\
(\mathrm{n}=5)\end{array}$ & $\begin{array}{l}250 \mu \mathrm{g} \\
(\mathrm{n}=5)\end{array}$ & $\begin{array}{l}500 \mu \mathrm{g} \\
(\mathrm{n}=5)\end{array}$ & $\begin{array}{l}1000 \mu \mathrm{g} \\
(\mathrm{n}=5)\end{array}$ & Pvalue \\
\hline $\begin{array}{l}\text { PUMPKIN } \\
\text { LEAVES }\end{array}$ & $100 \pm 0.00$ & $0.0 \pm 0.00 * *$ & $3.2 \pm 0.184 * * *$ & $1.7 \pm 0.104 * * *$ & $28.7 \pm 0.09 * * * * 1$ & $52.1 .0 \pm 1.15 * * * *$ & 0.0001 \\
\hline $\begin{array}{l}\text { SCENT } \\
\text { LEAVES }\end{array}$ & $100 \pm 0.00$ & $0.0 \pm 0.00^{*}$ & $7.02 \pm 0.178 * *$ & $15.0 \pm 0.240 * * *$ & $36.7 \pm 0.05 * * *$ & $63.6 \pm 0.59 * * * *$ & 0.0001 \\
\hline $\begin{array}{l}\text { BITTER } \\
\text { LEAVES }\end{array}$ & $100 \pm 0.00$ & $0.0 \pm 0.00 *$ & $16.05 \pm 0.150 * *$ & $26.28 \pm 0.44 * * *$ & $41.0 \pm 0.84 * * *$ & $76.68 \pm 6.43 * * * *$ & 0.0001 \\
\hline
\end{tabular}

Table-2: Determination of phyto-toxicity using the pumpkin leave equivalent at the various concentration on human erythrocyte

\begin{tabular}{|l|l|l|l|l|l|l|}
\hline Conc & $\begin{array}{l}\text { Absorbance } \\
\text { PLE= } \\
\mathbf{P}\end{array}$ & $\begin{array}{l}\text { Triaton X } \\
\text { U (Absorbance) } \\
\mathbf{5 4 0 n m}\end{array}$ & $\begin{array}{l}\text { PBS } \\
\mathbf{U} \text { (Absorbance) } \\
\mathbf{5 4 0 n m}\end{array}$ & $\begin{array}{l}\text { Telfairia } \\
\text { occidentalis } \\
\text { U (Absorbance) } \\
\mathbf{5 4 0 n m}\end{array}$ & $\begin{array}{l}\text { Vernonia } \\
\text { amygdalina } \\
\text { (Absorbance) } \\
\text { 540nm }\end{array}$ & $\begin{array}{l}\text { Ocimium } \\
\text { gratissimum } \\
\text { U(Absorbance) } \\
\text { 540nm }\end{array}$ \\
\hline $125 \mu \mathrm{g}$ & 3.2 & $100=31.25$ & $0.0=0$ & $3.2=1$ & $7.0=2.1$ & $16.5=5.15$ \\
\hline $250 \mu \mathrm{g}$ & 1.7 & $100=58.82$ & $0.0=0$ & $1.7=1$ & $15.0=8.8$ & $26.28=8.8$ \\
\hline $500 \mu \mathrm{g}$ & 28.7 & $100=3.48$ & $0.0=0$ & $28.7=1$ & $36.7=1.27$ & $41.0=1.4$ \\
\hline $1000 \mu \mathrm{g}$ & 52.1 & $100=1.92$ & $0.0=0$ & $52.1=1$ & $63.6=1.22$ & $76.6=1.22$ \\
\hline
\end{tabular}

Key: $\mathrm{PLE}=$ Pumpkin leave equivalent, $\mathrm{P}=$ absorbance values of pumpkin leave, $\mathrm{U}=$ Absorbance of unknown Phyto product, $\mathrm{PLE}=$ $\mathrm{U} / \mathrm{P}=\mathrm{PLE}$. Vernonia amygdalina (Bitter leave), Ocimium gratissimum (Scent Leave), Telfairia occidentalis (pumpkin leave) 


\section{RESULTS}

Pumpkin Leave Equivalent $(\mathrm{PLE})=\mathrm{U} / \mathrm{P}$

$\mathrm{U}=$ (Hemolytic concentration of the unknown)

$\mathrm{P}=($ Minimal hemolytic concentration of Pumpkin leaves)
PLE is in $\mu \mathrm{g} / \mathrm{ml}$ and from the

Toxicological point of view useful values range from

$>1=$ More toxic than Telfaira occidentalis

$\leq 1=$ Less Toxic or as phyotoxic as Telfaira occidentalis

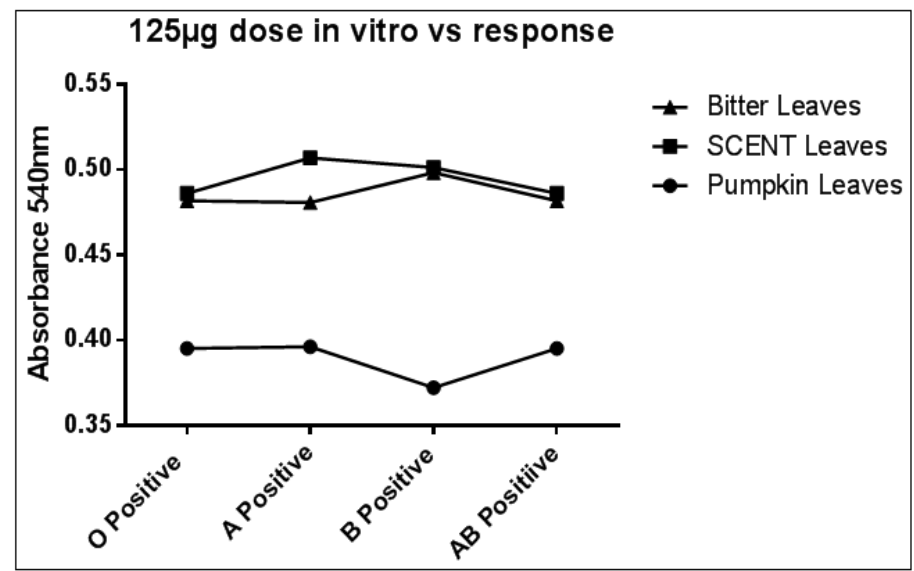

Fig-1: Comparative effect of 125mg dose of Telfaira ocidentalis, Ocimum gratissimum, and Vernonia amygdalina (Pumpkin, Scent and Bitter leaves) extract on the human ABO blood groups to determine its toxicity at absorbance values

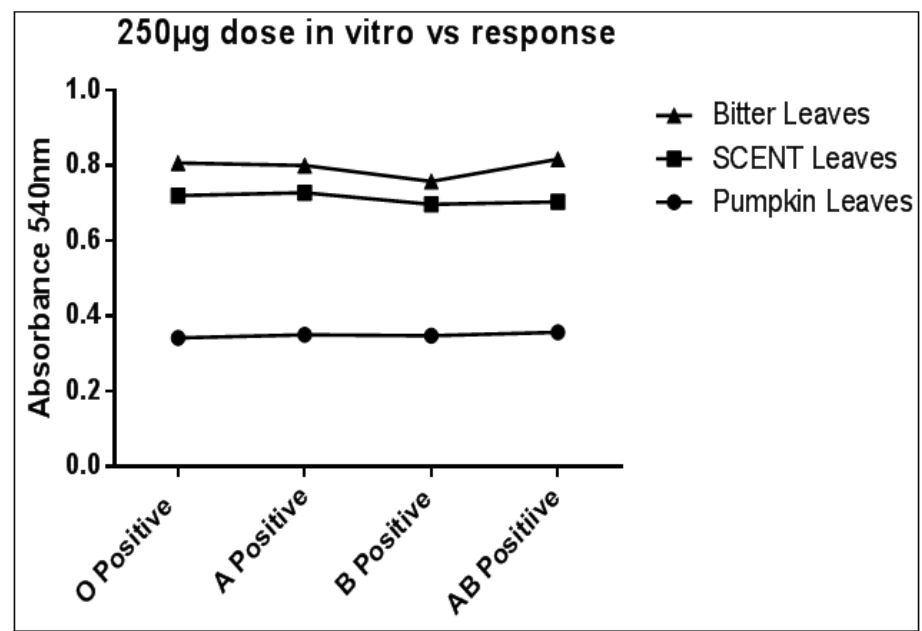

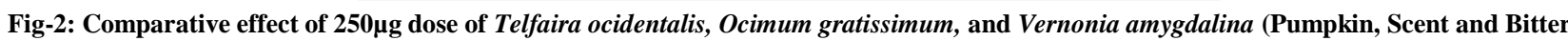
leaves) extract on the human $\mathrm{ABO}$ blood groups to determine its toxicity at absorbance values

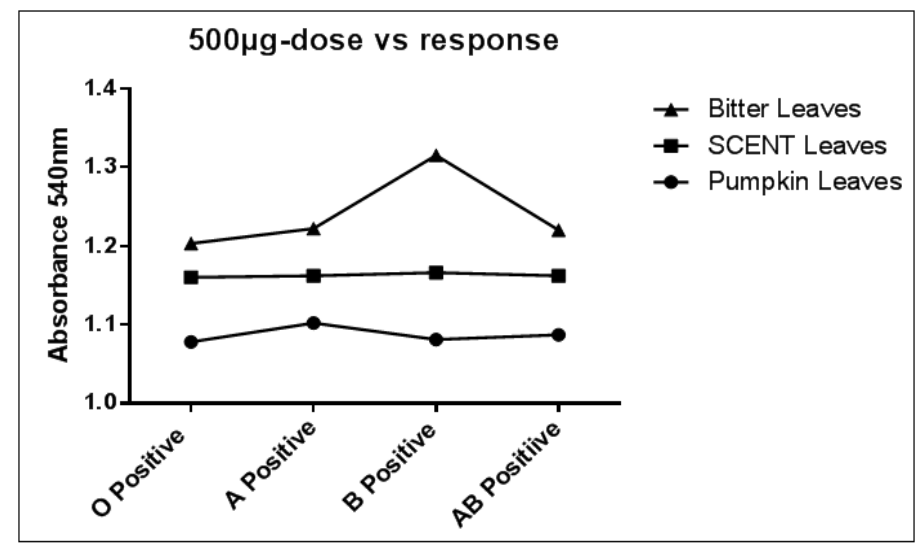

Fig-3: Comparative effect of 500mg dose of Telfaira ocidentalis, Ocimum gratissimum, and Vernonia amygdalina (Pumpkin, Scent and Bitter leaves) extract on the human $\mathrm{ABO}$ blood groups to determine its toxicity at absorbance values 


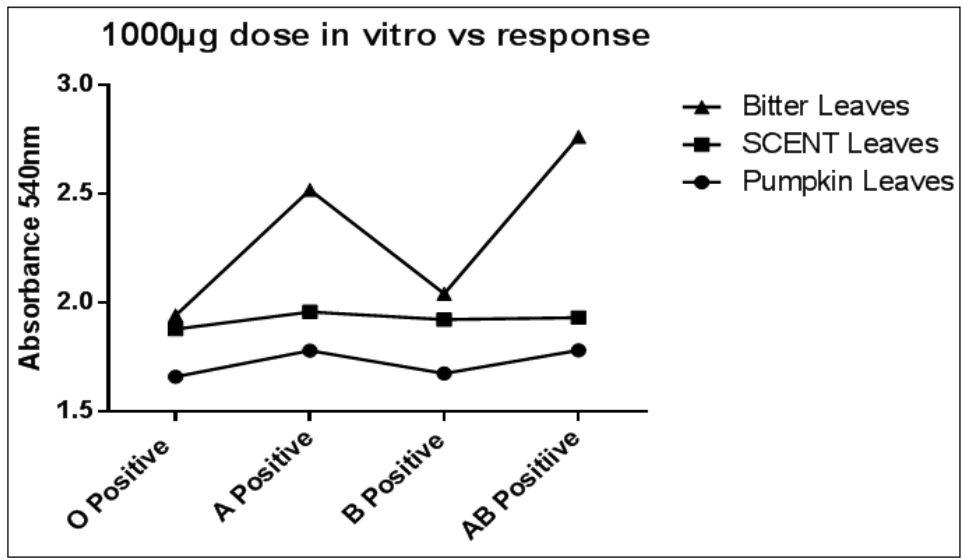

Fig-4: Comparative effect of 1000mg dose of Telfaira ocidentalis, Ocimum gratissimum, and Vernonia amygdalina (Pumpkin, Scent and Bitter leaves) extract on the human $\mathrm{ABO}$ blood groups to determine its toxicity at absorbance values

\section{DISCUSSION}

This study showed an elevated the hemolytic effect on the human erythrocyte as the concentration increased which showed that at a higher concentration Telfaira occidentalis shows some level of toxicity on human erythrocyte conferring with the dose dependent toxicity this is synonymous with studies carried out by [28-30] which discovered a lethal concentration of Telfaira occidentalis at high concentration.

The in vitro effect of Telfaira occidentalis, Vernonia amygdalina and Occimium gratissimium there was a significant difference on all the concentration gradient on human erythrocytes comparatively $(\mathrm{p}<0.05)$. Telfaira occidentalis had a less toxic effect on human erythrocyte with the least percentage hemolysis of (3.4, 1.7, 28.7 and 52.1\%) as compared with Vernonia amygdalina which showed an increased toxicity with percentage hemolysis of (16.05, 26.2, 41.0 and 76.6\%) this is synonymous with studies carried out by) [31-33]. Occimium gratissimium leave extract showed a reduced hemolysis as compared with Vernonia amygdalina but significantly higher than that of Telfaira occidentalis in vitro $(7.02,15.0,36.7$ and $63.6 \%)$ at $125,250,500$ and $1000 \mu \mathrm{g}$ concentration respectively.

The stabilizing effect of Telfaira occidentalis on human erythrocyte as observed in this study may be due to the action of the extracts (leaf, stem and seed) which is proposed to likely be due to prevention of two main erythrocyte sickling pathways; the $\mathrm{Ca}$ high $\mathrm{K}+$ and $\mathrm{Mg} 2+2+$ activated $\mathrm{K}+$ efflux and $\mathrm{K}-\mathrm{Cl}$ co-transport Channels which promotes the rehydration of the cells and also exhibit synergy with the protective phyto-chemicals like the haematopoietic glycosides, saponins and the alkaloids present in the aqueous pumpkin leave extract) $[6,7,25,26]$.

The essence of using pumpkin as an equivalent for determining the phyotoxicity of substance on human erythrocyte stems from the stabilisng effect Telfaira occidentalis has on the human erythrocyte which prompt its usage thus the least concentration at $250 \mu \mathrm{g}$ is determined as the pumpkin equivalent. To determine the equivalent of other phyto-product using the equivalent is calculated using the least concentration which had the least hemolysis on Telfaira occidentalis divided by the least concentration of other phyto-extract. The equivalent greater than one shows that the toxicity is higher than Telfaira occidentalis, the equivalent less than one shows a toxicity lower than pumpkin equivalent but the when is it equals to one, it is equals to that of pumpkin [27-34].

Pumpkin Leave Equivalent $(\mathrm{PLE})=\mathrm{U} / \mathrm{P}$

$\mathrm{U}=$ (Hemolytic concentration of the unknown)

$\mathrm{P}=($ Minimal hemolytic concentration of Pumpkin leaves)

PLE is in $\mu \mathrm{g} / \mathrm{ml}$ and from the toxicological point of view useful values range from

$>1=$ More toxic than Telfaira occidentalis

$\leq 1=$ Less Toxic or as phyotoxic as Telfaira occidentalis) [27].

\section{CONCLUSION}

From the results obtained in this study Telfiara occidentalis has a potential as a tool for determining phyto-toxicity. However there is still need for further studies to evaluate its sensitivity, specificity and accuracy.

\section{ACKNOWLEDGEMENT}

All thanks to the National Academy for the Advancement of science for the assistance in grants and works space.

Conflict of Interest: There were no conflicts of interest.

\section{REFERENCE}

1. Akorode M. Ethnobotany of Telfairiaoccidentalis (Cucurbitaceae) among Igbos of Nigeria. Ecological Botanica; 1990;44(1): 29-39. 3. 
2. Alvarez L, Gil AG, Ezpeleta O, Jalon-Garcia JA, Cerain L. Immunotoxic effects of Ochratoxin A in Wistar rats after oral administration. Food and Chemical Toxicology, 2004; 42:825-834.

3. Alvarez L, Gil AG, Ezpeleta O, Jalon-Garcıa JA, Cerain L. Immunotoxic effects of Ochratoxin A in Wistar rats after oral administration. Food and Chemical Toxicology; 2004;42: 825-834.

4. Aminu M, Bello MS, Abbas O, Aliyu M, Malam BS, Auwalu G, Muhammad HA, Shafi'u M, Hussaina NN, Hasiya A, Sani A. Comparative in vitro antioxidant studies of ethanolic extracts of Psidiumguajava Stem Bark and Telfairiaoccidentalis leaf. International Journal of Modern Biochemistry; 2012;1(1):18-26. 11.

5. Amresh G, Singh PN, Rao CV. Toxicological screening of traditional medicine Laghupatha (Cissampelospareira) in experimental animals. Journal of Ethnopharmacology; 2008;116:454-460.

6. An X, Mohandas N. Disorders of red cell membrane. British Journal of Haematology. 2008;141(3):367-75.

7. Andrews RK, Lopez JA, Berndt MC. Molecular mechanisms of platelet adhesion and activation. The International Journal of Biochemistry and Cell Biology; 1997;29:91-105.

8. Anisuzzaman ASM, Sugimoto N, Sadik G, Gufor MA. Sub-acute toxicity study of 5-hydroxy-2 (hydroxyl-methyl) 4H-pyran-4-one, isolated from Aspergillus fumigates. Pakistan Journal of Biological Science; 2001;4:1012-1015.

9. Bafor EE, Igbinuwen O. Acute toxicity studies of the leaf extract of Ficusexasperata on haematological parameters, body weight and body temperature. Journal of Ethnopharmacology; 2009;123:302-307.

10. Center for Drug Evaluation and Research (CDER). Guidance for Industry. Single Dose Acute Toxicity Testing for Pharmaceuticals. Food and Drug Administration (FDA), USA, 1996;1-2.

11. Cohen WD. The cytomorphic system of anucleate non-mammalian erythrocytes. Protoplasma. 1982;113: 23-32.

12. Commission Directive. Amending Directive 2001/83/EC of the European Parliament and of the Council on the Community Code Relating to Medicinal Products for Human Use (63/EC of the 25th June 2003). Annex I, Official Journal of the European Communities L159 27/6/ 2003, Brussels, pp. 46-94, 2003.

13. Cragg MG, Newman DJ (2001). Natural product drug discovery in the next millennium. Pharmaceutical Biology; 39:8-17.

14. Criswell K, Sulhanen A, Hochbaum AF, Bleavens M (2002). Effect of PHZ or phlebotomy on peripheral blood, bone marrow and erythropoietin Wistar rats. Journal of Applied Toxicology; 20:25-29.
15. Da Silva J, Herrmann SM, Heuser V, Peres W, Marroni NP, Gonzalez-Gallego J, Erdtmann B (2002). Evaluation of the genotoxicity affect of rutin and quercetina by comet assay and micronucleus test. Food and Chemical Toxicology; 40: 941-947.

16. Demma J, Gebre-Mariam T, Asres K (2007). Toxicological study on Glinuslotoides: A traditionally used taenicidal herb in Ethiopia. Journal of Ethnopharmacology; 111:451-457.

17. Denomme GA (2004). "The structure and function of the molecules that carry human red blood cell and platelet antigens". Transfusion Medicine Reviews. 18 (3): 203-31.

18. Diesen DL, Hess DT, Stamler JS (2008). "Hypoxic vasodilation by red blood cells: evidence for an s-nitrosothiol-based signal". Circulation Research. 103 (5): 545-53. doi.

19. Dobrovolskaia, M. A. \& McNeil, S. E(2013). Understanding the Correlation Between In Vitro and In Vivo Immunotoxicity Tests for Nanomedicines. Journal of controlled release 172, 456-458

20. Duffus JH, Worth HGJ (2006). Introduction to Toxicology. In: Fundamental Toxicology 2nd edition, RSC publishing, UK,Pp 1-234.

21. Dybing E, Doe J, Groten J, Kleiner J, O`Brien J, Renwick AG, Schlatter J, Steinberg P, Tritscher A, Walker R, Younes M (2002). Hazard characterisation of chemicals in food and diet: dose response, mechanisms and extrapolation issues. Food and Chemical Toxicology; 40: 237-282.

22. Harrison, K. L. (1979). "Fetal Erythrocyte Lifespan". Journal of Paediatrics and Child Health. 15 (2): 96-97.

23. Hasumura $M$, Yasuara $K$, Tamura $T$, Imai $T$, Mitsumori K, Hirose M (2004). Evaluation of the toxicity of enzymatically decomposed rutin with 13-weeks dietary administration to Wistar rats. Food and Chemical Toxicology; 42: 439-444.

24. Hayes AW(2001). Principles and Methods of Toxicology 4th edition, Raven Press, New York Pp1-650.

25. Higgins, John (2014). "Red Blood Cell Population Dynamics". Clinics in Laboratory Medicine. 35 (1): 43-57.

26. Hillman, Robert S.; Ault, Kenneth A.; Rinder, Henry M. (2005). Hematology in Clinical Practice: A Guide to Diagnosis and Management (4). McGraw-Hill Professional. Pp. 1-230.

27. Ibeh N.I, Okungbowa M.A, Ekrakena T, Ibeh IN. Erythrocytotoxicity of effects of Telfaira occidentalis leaves extracts on human erythrocyte: Results of an invitro phyto-toxicity study on Human erythrocyte. Asia Pacific Journal of Medical Toxicology. 2019;8(4):121-125.

28. Idris S. Compositional Studies of Telfairiaoccidentalis leaves. American Journal of Chemistry, 2011;1(2):56-59. 
29. Iolascon A, Perrotta S, Stewart GW. Red blood cell membrane defects. Reviews in Clinical and Experimental Hematology. 2003;7(1):22-56.

30. Izzo A. Drug interactions with St. John's Wort (Hypericumperforatum): A review of the clinical evidence. International Journal of Clinical Pharmacology and Therapeutics; 2004;42:139-148.

31. Mbaka GO, Adeyemi OO, Oremosu AA. Acute and sub-chronic toxicity studies of the ethanol extract of the leaves of Sphenocentrumjollyanum
(Menispermaceae). Agriculture and Biology Journal of North America; 2010;1:265-272.

32. McLaren CE, Brittenham GM, Hasselblad V. Statistical and graphical evaluation of erythrocyte volume distributions. American Journal Physiology. 1987;252(4):24-27.

33. Mohandas N, Gallagher PG. Red cell membrane: past, present, and future. Blood. 2008;112(10):3939-3948. 